\title{
Frequency of Occurrence of Different Types of Leucoderma and Vitiligo, Rishi, Dasna, Ghaziabad, India
}

\author{
Kirti M. Tripathi", Savita Arya and Vinita Singh
}

Krishi Vigyan Kendra, Bulandshahr, Mujaffarnagar and Gautam Budh nagar, India

*Corresponding author

\section{A B S T R A C T}

Keywords

Frequency, Occurrence, Types of Leucoderma, Ghaziabad

Article Info

Accepted:

10 August 2018

Available Online:

10 September 2018
120 patients of Leucoderma and Vitiligo of Rural - cum industrial Skin and Health Institute, Dasna, Ghaziabad were assessed to see the frequency of occurrence and associated ailments of the disease. Patients of all age group were selected. Awareness of the respondents about the disease, sensation test (sensation present in the white lesions), opinion about the cause of the disease was assessed through interview schedule. Results showed that in different income groups majority of patients $(33.33 \%)$ were suffering from Vitiligo Vulgaris. Majority of respondents (49.10\%) had no awareness about the disease. Many respondents $(75 \%)$ had no physical problem, but had psychological problems like shyness, ashamed of going outside, fear and prejudice etc. All the 120 patients had sensation in their white lesions. It was defined that in 1-10 Years of age group disease was progressing very fast and above 20 years of age group the progression was static. Results reveal that nutritional status of all the age groups of HIG was better than LIG and MIG.

\section{Introduction}

The skin of an adult weighs an average of $4 \mathrm{~kg}$ and covers an area of $2 \mathrm{~m}^{2}$. It has 3 layers: the outer epidermis, a vascular epithelium, which is firmly attached to, and supported by, connective tissue in the underlying dermis, beneath the dermis a layer of loose connective tissues, the hypodermis, which often contains abundant fat. Skin is one of the most important parts of mammalian body as it performs different functions, for e.g. it protects against chemicals, particles, UV radiations. It also protects our body from the invasion of different microbes which may cause infections (Bennette et al., 1992).
There is a general belief that skin diseases cannot be cured. The fact, however, is that skin diseases being visible on the surface are far more easily amenable to treatment than the diseases belonging to any other medical speciality with the progress made during the last few decades, it has become possible to control and even cure several of the so called incurable skin diseases (NIAMS, June 2014).

Colour of the skin is constituted of 3 components: Melanin which contribute black colour, Haemoglobin which is related to red or blue colour depending upon its state of oxidation or reduction and Keratin, which gives light yellow colour. Disorders of 
pigmentation can arise either due to a disturbance in the formation of melanin or its loss from the skin, but occasionally, other causes such as, incontinence of melanin towards the dermis in various disease or deposition of other extraneous pigments may also be responsible for pigmentary disorders.

The word Vitiligo itself is said to have been first used by Celsus in his Latin medical classic "De Medicina" in the $1^{\text {st }}$ centuary A.D. Some suggested that the word vitiligo comes from the Latin word for veal because the white skin has an appearance resembling the white glistening of the flash of calves (vituli).

Vitiligo is a disease characterized by disappearance of melanocytes from the skin. It can negatively influence the physical appearance of affected individuals, and may profoundly affect a person's psychosocial function and quality of life (Kruger, C. et al., 2015)

Home-based phototherapy is another territory that is showing great advancements (Tien Guan et al., 2015).

Psoralea corylifolia L. has been used traditionally as medicine in China and recommended for the treatment of stomachic, deobstruent, anthelmintic, diuretic, vitiligo and also certain skin diseases, e.g., leucoderma, psoriasis and leprosy (Kotiyal and Sharma, 1992; Zhu, 1998).

Hann et al., (1999) defined that vitiligo is best defined as an acquired, progressive disorder that selectively destroys some of or all melanocytes residing in the inter follicular epidermis and occasionally in the hair follicles are well defined.

Hann et al., (1991) made it evidential that Vitiligo and Leucoderma are caused by stoppage of melanin formation by the melanocytes and thus the characteristic lesion is a depigmented macule without any part of the body including the mucous membranes of the lips and genitals. Some of lesions or parts may be hypopigmented and not completely depigmented. In some lesions or some parts of the lesions hairs may also be white (Leucotrachia), the melanocytes are completely absent from hair. The margins of the lesions are generally well defined and may be hyper pigmented in some cases.

Leucoderma is physiologically not critical but they are socially and psychologically devastating. Some people mistook as leprosy, because of white spots, which also appear in leprosy sometimes. But both are very different from each other. White patches of leprosy have no sensations whereas of vitilgo have sensations.

Halder et al., (2007) both the diseases are categorized into Trichrome vitiligo, where depigmentation, hypopigmentation and normal or hyperpigmentation occurs in the same lesion.

Distribution is confined to mucocutaneous junctions or acral parts of the body-face, hands and feet in Acrofacial vitiligo. In Vitiligo vulgaris distribution is randomly all over the body. In Halo Naveous, the lesions are oval or circular. There is sharply defined hypo or depigmented halo around mole.

Vitiligo can also be divided on the basis of articles used like due to pressure on the flanks of ladies who wear a tight petticoat string. Lesions are located on the dorsa of the feet in a pattern corresponding to the straps of the slippers or shoes. Such cases are believed to be caused by the action of Monobenzyl ether of hydroquinone $(\mathrm{MBH})$. Rubber and plastic can also cause vitiligo on the hands due to the rubber or plastic gloves, on the forehead in the region where the plastic bindi is applied, on 
the breast if the patient uses rubber padded brassier or keeps purse in this region.

Superstitious people recognize it as "paap" or "devi ka prakop". Some think it is infectious and can spread through sharing cloths, food and water with diseased person. All these are myths and of no meaning and no connection with disease. It is very painful to see those young children and adolescent girls and boys, who suffer from these diseases. Because person suffering from leucoderma and vitiligo undergo social isolation, frustration, feeling of being discarded, hatred, fear and prejudice (Ezzedine et al., 2015)

There is a strong felt need to assess the occurrence of the patients suffering from these diseases and making people aware of the fact that the diseased person can be as efficient physically, mentally and sexually as any other normal individual (Chopra et al., 2017)

The prevalence of vitiligo varies in different geographic regions and different sample size, and the data have limitations and localizations. Besides, the disorder afflicts various ethnic populations with varying prevalence estimates ranging from $0.1 \%$ to $2.0 \%$ based on the general populations in previous studies (Majumder, 2000 and Alkhateeb et al., 2003).

\section{Materials and Methods}

Besides the secondary data, collection of the primary data, related to the subject had also been done on the basis of purposive sampling. 120 subjects in 3 months had been interviewed of different age groups and income range, to assess the empirical validity of the theoretical concepts on the subjects for the study. The interview was conducted by using an interview schedule at RISHI (Rural Cum Industrial skin and health institute), Dasna, Ghaziabad. This institute has large number of patients from Uttar Pradesh as well as New
Delhi. As it is a skin institute and situated in the periphery of Ghaziabad district therefore all income groups visit for treatment. Income groups were divided as low income group $(\mathrm{LIG})=40$, middle income group $(\mathrm{MIG})=40$ and high income group $(\mathrm{HIG})=40$. They were further divided into age groups 1-10 years, 1120 years and $>20$ years to find out the prevalence and rate of progression of disease. Sensation test was conducted (pinch method) to find out the sensation in lesions. Presence of Leucotrichia (whitening of hair on lesions) was diagnosed in the presence of Dermatologist.

As evident from Table 1 maximum numbers of respondents were suffering from Vitiligo Vulgaris (33.33\%) from all three groups. $3.33 \%$ had Halo Naveous type of vitiligo. In HIG, the prevalence of AV, TV and CL were found to be equal. This may be due to appropriate diet and following the precautions told by doctor in appropriate manner.

From Table 2 it can be concluded that in LIG, majority of respondents $(40 \%)$ were from age group 10-12 years. In contrary, 35\% respondents were there each from 1-10 years and >20 years in MIG and HIG both. It is clear that in all the three groups $35 \%$ of the respondents were from age group 1-10 years. This showed that number of children getting trapped by diseases was more.

The prevalence of the disease was more $(35 \%)$ in females in LIG except from 10-20 years of age group where males were more $(25 \%)$. In MIG and HIG occurrence of the disease was more in males. This indicated that prevalence is more among males than females (Table 3).

This is ironical and can be studied from the Table 4 that maximum numbers of respondents (49.10) were absolutely unaware about different aspects of disease. $34.11 \%$ of them had very little awareness. It is evident 
that after the occurrence of disease very few numbers of respondents acquired awareness.

Skin and blood disorders and superstitious thoughts like evil spirit etc.

When it came to the causes of disease, majority of total respondents said that it is due to hereditary. $55 \%$ from HIG told that it was due to hereditary, as from the past history some of their grandparents were suffering from this disease so they acquired from them. In MIG, Most of them conveyed that it was god's will that they are suffering from this disease. $18.33 \%$ had a thought that it is a kind of skin or blood disorder and evil spirit was the reason behind this ailment (Table 5).

Table.1 Types of Vitiligo and Leucoderma in the respondents

\begin{tabular}{|c|c|c|c|c|c|c|}
\hline \multirow{2}{*}{$\begin{array}{l}\text { Income } \\
\text { Group }\end{array}$} & \multicolumn{5}{|c|}{ Types of Vitiligo and Leucoderma } & \multirow{2}{*}{$\begin{array}{l}\text { Total } \% \text { of } \\
\text { respondents }\end{array}$} \\
\hline & $* \mathrm{AV}$ & $* * \mathrm{VV}$ & $* * * \mathrm{TV}$ & $* * * * \mathrm{HN}$ & $* * * * * \mathrm{CL}$ & \\
\hline LIG & $14(35 \%)$ & $18(45 \%)$ & $6(15 \%)$ & - & $2(5 \%)$ & 100 \\
\hline MIG & $10(25 \%)$ & $14(35 \%)$ & $8(20 \%)$ & $2(5 \%)$ & $6(15 \%)$ & 100 \\
\hline HIG & $10(25 \%)$ & $8(20 \%)$ & $10(25 \%)$ & $2(5 \%)$ & $10(25 \%)$ & 100 \\
\hline $\begin{array}{l}\text { Total } \\
\text { Average }\end{array}$ & $28.33 \%$ & 33.33 & 20 & 3.33 & 15 & 100 \\
\hline $\begin{array}{l}* \mathrm{AV}=\mathrm{Acro} \\
* * \mathrm{VB}=\mathrm{Viti} \\
* * * \mathrm{TV}=\mathrm{Tri} \\
* * * \mathrm{HN}=\mathrm{H} \\
* * * * * \mathrm{CL}=\end{array}$ & $\begin{array}{l}\text { 1 Vitiligo } \\
\text { Vulgaris } \\
\text { me Vitiligo } \\
\text { Naveous } \\
\text { act Leucodel }\end{array}$ & & & & & \\
\hline
\end{tabular}

Table.2 Different age groups of patients

\begin{tabular}{|l|l|l|l|l|}
\hline Income Group & \multicolumn{2}{|l|}{ Age groups } \\
\hline & $1-10$ years & $10-20$ years & $>20$ years & Total \\
\hline LIG & $14(35 \%)$ & $16(40 \%)$ & $10(25 \%)$ & 100 \\
\hline MIG & $14(35 \%)$ & $12(30 \%)$ & $14(35 \%)$ & 100 \\
\hline HIG & $14(35 \%)$ & $12(30 \%)$ & $14(35 \%)$ & 100 \\
\hline Total Average \% & 35 & 33.33 & 31.67 & 100 \\
\hline
\end{tabular}


Table.3 Gender distribution of the patients

\begin{tabular}{|c|c|c|c|c|c|c|c|c|c|c|}
\hline \multirow[t]{2}{*}{ Income Group } & \multicolumn{3}{|c|}{ 1-10 Years } & \multicolumn{3}{|c|}{ 10- 20 years } & \multicolumn{3}{|c|}{$>20$ Years } & \multirow[t]{2}{*}{ Average } \\
\hline & Male & Female & Total average & Male & Female & Total average & Male & Female & Total average & \\
\hline LIG & $4(10 \%)$ & $10(25 \%)$ & 100 & $10(25 \%)$ & $6(15 \%)$ & 100 & $4(10 \%)$ & $6(15 \%)$ & 100 & \\
\hline MIG & $8(20 \%)$ & $6(15 \%)$ & 100 & $6(15 \%)$ & $6(15 \%)$ & 100 & $10(25 \%)$ & $4(10 \%)$ & 100 & \\
\hline HIG & $8(20 \%)$ & $6(20 \%)$ & 100 & $8(20 \%)$ & $4(10 \%)$ & 100 & $10(25 \%)$ & $4(10 \%)$ & 100 & \\
\hline $\begin{array}{l}\text { Total Average } \\
\%\end{array}$ & 16.67 & 18.33 & 100 & 20.00 & 13.33 & 100 & 20.00 & 11.67 & 100 & \\
\hline
\end{tabular}

Table.4 Awareness of the respondents about Vitiligo and Leucoderma

\begin{tabular}{|l|l|l|l|l|l|l|l|l|l|l|}
\hline $\begin{array}{l}\text { Awareness } \\
\text { Level }\end{array}$ & LIG & Male & Female & Average & MIG & Male & Female & & Male & Female \\
\hline No awareness & $12(66.67)$ & $16(72.73)$ & 69.70 & $10(41.67)$ & $6(37.50)$ & 39.59 & $6(23.08)$ & $8(57.14)$ & $(40.11)$ & 49.10 \\
\hline $\begin{array}{l}\text { Little } \\
\text { awareness }\end{array}$ & $2(11.11)$ & $4(18.18)$ & 14.65 & $14(58.33)$ & $8(50.00)$ & 54.16 & $10(38.46)$ & $4(28.57)$ & $(33.51)$ & 34.11 \\
\hline $\begin{array}{l}\text { Awareness } \\
\text { after disease } \\
\text { occurred }\end{array}$ & $4(22.22)$ & $2(9.09)$ & 15.65 & - & $2(12.50)$ & 12.50 & $10(38.46)$ & $2(14.28)$ & $26.36)$ & 16.07 \\
\hline Total & 100 & 100 & 100 & 100 & 100 & 100 & 100 & 100 & 100 \\
\hline
\end{tabular}

Table.5 Respondents opinion about the cause of the disease

\begin{tabular}{|l|l|l|l|l|}
\hline Causes & LIG & MIG & HIG & Sample Average \\
\hline Nutritional inadequacy & $8(20 \%)$ & $4(10 \%)$ & $2(5 \%)$ & $11.67 \%$ \\
\hline Genetic(Hereditary) & $8(20 \%)$ & $12(30 \%)$ & $22(55 \%)$ & - \\
\hline Lack of proper hygiene and sanitation & - & - & - & - \\
\hline Due to chemicals & $4(10 \%)$ & $4(10 \%)$ & $2(5 \%)$ & $8.33 \%$ \\
\hline God's will & $16(40 \%)$ & $10(25 \%)$ & $6(15 \%)$ & $26.67 \%$ \\
\hline Any other* & $4(10 \%)$ & $10(25 \%)$ & $8(20 \%)$ & $18.33 \%$ \\
\hline Total & $100 \%$ & $100 \%$ & $100 \%$ & $100 \%$ \\
\hline
\end{tabular}


Table.6 Problems associated with the disease in the respondents

\begin{tabular}{|c|c|c|c|c|c|c|c|c|c|c|c|c|c|c|c|c|c|c|c|}
\hline \multirow{2}{*}{$\begin{array}{c}\text { Associated } \\
\text { Problems }\end{array}$} & \multicolumn{5}{|c|}{ LIG } & \multirow[t]{2}{*}{ Ave } & \multicolumn{5}{|c|}{ MIG } & \multirow[t]{2}{*}{ Ave } & \multicolumn{5}{|c|}{ LIG } & \multirow[t]{2}{*}{ Ave } & \multirow{2}{*}{$\begin{array}{c}\text { Sample } \\
\text { Ave }\end{array}$} \\
\hline & AV & VV & TV & $\mathrm{HN}$ & CL & & AV & VV & TV & $\mathrm{HN}$ & CL & & AV & VV & TV & $\mathrm{HN}$ & CL & & \\
\hline Cough+Cold+* & $2(14.29 \%)$ & $\begin{array}{c}2 \\
(11.11 \%)\end{array}$ & & & & $6.35 \%$ & $2(20 \%)$ & - & - & - & - & $6.86 \%$ & $\begin{array}{c}2 \\
(20 \%)\end{array}$ & $4(50 \%)$ & $\begin{array}{c}4 \\
(40 \%)\end{array}$ & - & $2(20 \%)$ & $26 \%$ & $13.08 \%$ \\
\hline Constipation+** & $2(14.29 \%)$ & - & - & - & - & $3.57 \%$ & - & $\begin{array}{c}2 \\
(14.29 \%)\end{array}$ & - & - & - & $2.86 \%$ & - & - & - & - & - & - & $2.14 \%$ \\
\hline $\begin{array}{l}\text { Frequent+Fever+ } \\
\text { weakness+* }\end{array}$ & - & - & - & - & - & - & $2(20 \%)$ & - & $\begin{array}{c}2 \\
(25 \%)\end{array}$ & - & - & $9 \%$ & - & - & $2(20 \%)$ & - & - & $4 \%$ & $4.33 \%$ \\
\hline Stomachache+* & - & - & - & - & - & - & $2(20 \%)$ & $2(14.28 \%)$ & - & - & - & $6.86 \%$ & $\begin{array}{c}2 \\
(20 \%)\end{array}$ & - & - & - & - & $4 \%$ & $3.62 \%$ \\
\hline $\begin{array}{c}\text { Fever+ } \\
\text { Cough+Cold+* }\end{array}$ & - & - & - & - & - & - & $2(20 \%)$ & - & - & - & - & $4 \%$ & - & - & - & - & - & - & $1.33 \%$ \\
\hline $\begin{array}{l}\text { Constipation+ } \\
\text { Stomachache+* }\end{array}$ & - & - & - & - & - & - & - & - & - & - & - & - & - & $2(25 \%)$ & - & - & - & $5 \%$ & $1.07 \%$ \\
\hline $\begin{array}{c}\text { No physical Only } \\
\text { Psychological } \\
\text { problems+* }\end{array}$ & $\begin{array}{c}10 \\
(71.43 \%)\end{array}$ & $\begin{array}{c}16 \\
(88.89 \%)\end{array}$ & $\begin{array}{c}6 \\
(100 \%)\end{array}$ & - & $\begin{array}{c}2 \\
(100 \%)\end{array}$ & $90.08 \%$ & $\begin{array}{c}2 \\
(20 \%)\end{array}$ & $\begin{array}{c}10 \\
(71.45 \%)\end{array}$ & $6(\%)$ & $2(\%)$ & $6(\%)$ & $\begin{array}{c}73.29 \\
\%\end{array}$ & $\begin{array}{c}6 \\
(60 \%)\end{array}$ & $\begin{array}{c}2 \\
(25 \%)\end{array}$ & $\begin{array}{c}4 \\
(40 \%)\end{array}$ & $\begin{array}{c}2 \\
(100 \%)\end{array}$ & $\begin{array}{c}8 \\
(80 \%)\end{array}$ & $61 \%$ & $74.79 \%$ \\
\hline
\end{tabular}

Table.7 Progression of the disease in the respondents

\begin{tabular}{|c|c|c|c|c|c|c|c|c|c|c|c|c|c|}
\hline \multirow{2}{*}{$\begin{array}{l}\text { Progression } \\
\text { of the } \\
\text { disease }\end{array}$} & \multicolumn{3}{|l|}{ LIG } & \multirow[t]{2}{*}{ Ave } & \multicolumn{3}{|l|}{ MIG } & \multirow[t]{2}{*}{ Ave } & \multicolumn{3}{|l|}{ HIG } & \multirow[t]{2}{*}{ Ave } & \multirow{2}{*}{$\begin{array}{l}\text { Sample } \\
\text { Ave }\end{array}$} \\
\hline & $1-10$ yrs & $11-20 y r s$ & $>20 \mathrm{yrs}$ & & $1-10$ yrs & 11-20yrs & $>20 \mathrm{yrs}$ & & $1-10 \mathrm{yrs}$ & $11-20 y r s$ & $>20 \mathrm{yrs}$ & & \\
\hline Static & - & $4(25 \%)$ & $8(80 \%)$ & $35 \%$ & $6(42.86 \%)$ & $8(66.66 \%)$ & $10(71.42 \%)$ & $61.31 \%$ & $4(28.57 \%)$ & $4(33.33 \%)$ & $14(100 \%)$ & $53.97 \%$ & $49.76 \%$ \\
\hline $\begin{array}{l}\text { Progressing } \\
\text { very slowly }\end{array}$ & $2(14.29 \%)$ & $10(62.5 \%)$ & - & $25.69 \%$ & $2(14.29 \%)$ & $2(16.67 \%)$ & $2(14.9 \%)$ & $15.08 \%$ & $8(57.14 \%)$ & $8(66.67 \%)$ & - & $41.27 \%$ & $27.32 \%$ \\
\hline $\begin{array}{l}\text { Progressing } \\
\text { very fast }\end{array}$ & $12(85.71 \%)$ & $2(12.5 \%)$ & $2(20 \%)$ & $39.40 \%$ & $6(42.85 \%)$ & $2(16.67 \%)$ & $2(14.29 \%)$ & $24.60 \%$ & $2(14.29 \%)$ & - & - & $4.76 \%$ & $22.29 \%$ \\
\hline Total & 100 & 100 & 100 & 100 & 100 & 100 & 100 & 100 & 100 & 100 & 100 & 100 & 100 \\
\hline
\end{tabular}


Table.8 Presence of Leucotrichia in the patients

\begin{tabular}{|c|}
\hline Income Group \\
\hline LIG \\
\hline MIG \\
\hline HIG \\
\hline Sample Average \\
\hline
\end{tabular}

\begin{tabular}{|c|c|}
\hline \multicolumn{2}{|c|}{ Presence of Leucotrichia } \\
\hline Male & Female \\
\hline $6(60 \%)$ & $4(40 \%)$ \\
\hline Male & Female \\
\hline $16(61.50 \%)$ & $10(38.50 \%)$ \\
\hline Male & Female \\
\hline $10(62.5 \%)$ & $6(37.50 \%)$ \\
\hline $61.33 \%$ & $38.67 \%$ \\
\hline
\end{tabular}

Total no. of respondents having Leucotrichia

\begin{tabular}{c}
$10(100 \%)$ \\
\hline $26(100 \%)$ \\
$16(100 \%)$ \\
$100 \%$
\end{tabular}

Table.9 Presence of sensation in the white lesions of the patients of Leucoderma and Vitiligo

\begin{tabular}{|l|c|c|}
\hline Income Group & No. of patients having sensation & Total \\
\hline LIG & $40(100 \%)$ & $100 \%$ \\
\hline MIG & $40(100 \%)$ & $100 \%$ \\
\hline HIG & $40(100 \%)$ & $100 \%$ \\
\hline Sample Average & $100 \%$ & $100 \%$ \\
\hline
\end{tabular}


Psychological problems like mental depression, shyness, ashamed, fear of going out and prejudice, etc. (Table 6).

In Table 7 it is shown that majority of respondents (74.79) had no associated physical problem at all. But due to presence of white patches in the body they were going through the state of mental illness like depression, shyness in going out, ashamed and fear to face society and prejudice. From the results it can be seen that $13.08 \%$ of respondents had frequent cough and cold which may be due to less immunity. Other associated ailments were found to be negligible.

Progression of the disease is mostly static $(49.76 \%)$ in all the three groups where the majority goes to $100 \%$ in age group $>20$ years of HIG. Progression is fast in 1-10 years of age group of LIG. This may be due to unsystematic medical treatment or proper diet (Table 8).

The whitening of hair of the lesion was to be found maximum in males $(61.33 \%)$ whereas in females it appeared in $38.67 \%$ of females. Majority of them came from MIG (Table 9).

While doing the sensation test of the patches of the lesions of patients, it was observed that $100 \%$ of them from all the three groups. This shows that leucoderma and vitiligo patches progress with sensation in them.

Prevalence of leucoderma and vitiligo is increasing at faster rate. The researcher came across many such cases while conducting the study. This is irony that India being getting advanced day by day facing such conditions frequently. The most remarkable point was that still this disease is not accepted by society. Unawareness is one of the major causes behind this fact. Children with their parents were easy to converse with but patients more than 15 years were much ashamed of coming and answering the questions. Food and dietary pattern and its effect on the treatment need to be focussed further more. It can also be concluded that progression of disease was static in older age groups and fast in younger. As per the conversation with dermatologists, it can be controlled with medication and appropriate diet.

\section{References}

"Questions and Answers about Vitiligo". NIAMS. June 2014. Archived from the original on 21 August 2016. Retrieved 11 August 2016.

Alkhateeb, A., P.R. Fain, A. Thody, D.C. Bennett and R.A. Spritz. 2003. Epidemiology of vitiligo and associated autoimmune diseases in Caucasian probands and their families. Pigment Cell Res, 16(3): 208-14.

Bennett, R.G. 1992. Anatomy and physiology of the skin. In: Papel I.D., Nachlas N.E. (Eds.) Facial Plastic and Reconstructive Surgery. Mosby, St. Louis; p.3-13.

Chopra, Parul; Rageshree, Niyogi and Katyal, Gaur. I 2009. Skin and Hair Care: Your Questions Answered. Byword Books Private Limited; p. 2.

Ezzedine, K., V. Eleftheriadou; M. Whitton and N. van Geel 2015. "Vitiligo". Lancet. $\quad 386 \quad$ (9988): 74-84. doi:10.1016/s0140-6736(14)607637.

Halder, R. M., et al., (2007). "Vitiligo". In Wolff, K., et al., Fitzpatrick's Dermatology in General Medicine (7th ed.). New York: McGraw-Hill Professional.

Hann, S. K., Chun, W. H. 1999, Clinical feature of Vitiligo. Clinics in dermatology 5,891-897.

Hann, S.K., Chun, W. H. (1991). A study of the lesions of vitiligo. Archives of Dermatology 91, 302-305. 
Kotiyal, J. P. and D. P. Sharma. 1992. Phytochemical studies of Psoralea species. Bulletin of MedicoEthnobotanical Research, 13; 209-223.

Kruger, C. and K.U. Schallreuter. 2015. Stigmatisation, avoidance behaviour and difficulties in coping are common among adult patients with vitiligo. Acta Derm Venereol, 95(5):553-558.

Majumder, P.P. 2000. Genetics and prevalence of vitiligo vulgaris. In:Hann
SK, Nordlund JJ, editors. Vitiligo. Oxford: Blackwell Science; pp.18-20.

Tien Guan, S.T., C. Theng and A. Chang. 2015. Randomized, parallel group trial comparing home-based phototherapy with institution-based 308 excimer lamp for the treatment of focal vitiligo vulgaris. $J$ Am Acad Dermatol, 72(4):733-5.

\section{How to cite this article:}

Kirti M. Tripathi, Savita Arya and Vinita Singh. 2018. Frequency of Occurrence of Different Types of Leucoderma and Vitiligo, Rishi, Dasna, Ghaziabad, India. Int.J.Curr.Microbiol.App.Sci. 7(09): 1267-1276. doi: https://doi.org/10.20546/ijcmas.2018.709.151 